\title{
An Econometrics Validation of Malthusian Theory: Evidence in Nigeria
}

\author{
Musa Abdullahi Sakanko1, Joseph David ${ }^{2}$
}

\begin{abstract}
Rising population is an asset, provided, the skills of the workforce are used to the maximum extent. If not appropriately channelized, it can be a liability for a nation. A skilled and hardworking population can emerge as a foundation for a country's development. This study examines the validity of Malthusian Theory in Nigeria using time series data from 1960 to 2016, employs the ARDL bound test techniques. The result shows that in the long-run, population growth and food production move proportionately, while population growth poses a depleting effect on food production in the short-run, thus validating the incidence of Malthusian impact in Nigerian economy in the short-run. The researcher recommended the government should strategize plans, which will further intensify family planning and birth control measure, compulsory western education and revitalization of the agricultural sector.
\end{abstract}

Keywords: Malthusian theory, population, ARDL bound testing

\begin{abstract}
Abstrak
Meningkatnya populasi ialah suatu aset, selama keterampilan tenaga kerja digunakan semaksimal mungkin. Jika tidak disalurkan dengan benar, itu bisa menjadi kewajiban bagi sebuah negara. Populasi yang terampil dan pekerja keras dapat muncul sebagai fondasi pembangunan suatu negara. Studi ini menguji validitas Teori Malthusian di Nigeria dengan menggunakan data deret waktu dari tahun 1960 sampai 2016, menggunakan teknik uji terikat ARDL. Hasilnya menunjukkan bahwa dalam jangka panjang, pertumbuhan penduduk dan produksi pangan bergerak secara proporsional, sementara pertumbuhan penduduk menimbulkan dampak yang menipis pada produksi pangan dalam jangka pendek, sehingga memvalidasi kejadian efek Malthus pada ekonomi Nigeria dalam jangka pendek. Peneliti merekomendasikan agar pemerintah menyusun rencana strategis, yang selanjutnya akan mengintensifkan ukuran keluarga berencana dan pengendalian kelahiran, pendidikan barat wajib dan revitalisasi sektor pertanian.
\end{abstract}

Kata Kunci: teori Matlhus, populasi, pengujian ARDL

\section{How to Cite:}

Sakanko, M.A. \& David, J. (2018). An Econometrics Validation of Malthusian Theory: Evidence in Nigeria. Signifikan: Jurnal Ilmu Ekonomi. Vol. 7 (1): 77 - 90. doi: http//dx.doi.org/10.15408/sjie.v7i1.6461 


\section{Introduction}

The study on the relationship between population growth and the means of sustenance (food supply or the growth of output) have generated serious tussle in the field of economics and demography. Zhang (2015) was of the view that, even though people don't usually take the effect of population growth on the development of an economy serious, increase in the population requires a proportionate increase in food production, means of subsistence, natural resources and even living area.

The first person to give serious attention to the exponential growth of population and its adverse effect on humanity was Reverend Thomas Robert Malthus (Ewugi and Yakubu, 2012) in his 1798 essay titled "An Essay on the Principle of Population." Malthusian Theory is the earliest theory of population presented by Reverend Thomas Robert Malthus in 1798, which was in opposition to the widespread 18th-century European view that society was continually improving, intending to point out the dangers of excessive population growth (Harley, 2017; Ewugi and Yakubu, 2012). Population, according to him if not checked by some preventive or positive ways doubles exponentially at every quarter of a century exceeding the growth of food production (Chand, 2017; Seth, 2017; Harley, 2017). Thus if preventive checks, like avoidance of marriage, later marriage or fewer children per marriage, are not exercised, then positive checks, like war, famine, and disease, will operate (Seth, 2017; Chand, 2017).

The Malthusian theory explains the relationship between population growth and food supply. The theory states that due to the natural sex instinct in human beings to increase at a fast rate, every quarter of a century, population if unchecked increases in a geometrical progression or exponentially quicker than means of sustenance (food supply) which increases in an arithmetic progression. Due to the workings of the law of diminishing returns and the assumption of a fixed quantity of land which tends to leads to vice or misery (Chand, 2017). He, therefore, envisaged two checks to control population growth to be par with the means of sustenance preventive and positive checks (Seth, 2017). The former affects the birth rate (such as marrying at a later age, abstaining from procreation, birth control, and homosexuality), positive checks increases the death rate (such as disease, war, disaster, and famine) (Seth, 2017). Thus if preventive checks not exercise, then positive checks, like war, famine, and disease, will operate (Seth, 2017 and Chand, 2017). Though, Malthus did not consider several factors, such as the improvement in farming techniques, the opening of new lands, advancement in medicine which reduced the mortality rate and technological progress in transportation. He asserts that these improvements were "merely to postpone the evil day" (Hanson, 1977 in Ewugi and Yakubu, 2012; Chand, 2017).

Even though the Malthusian theory was to some extent proved wrong in developed countries during the 20th century due to the enormous improvement in medical sciences which greatly brought down the death rates (Friedman, 2000 in Ewugi and Yakubu, 2012) and the technological advancement in agriculture which increased food production, developing countries had over the years experienced tremendous growth in their population growth although with a seesawing growth in outputs which is accompanied with increase in poverty rate, wars, tribal and religious crisis, decline in living standard, and disease outbreak which fits into the pessimistic prediction of the Malthusian theory. In Nigeria, the 1952/1953 census 
puts its total population at 30.4 million with a growth rate of $2.1 \%$, while the 1963 and 1991 census put Nigeria's population at 55.6 million and 88.5 million with growth rates of 5.6\% and 2.6 respectively (Andrew, 2002 in Ewugi and Yakubu, 2012). Although the 2006 census put the total population at 140 million, eleven years after, the estimated population of Nigeria stood at 193 million which placed the country as the most populated in Africa and 7 th in the world, with a population growth rate of $2-3.3 \%$ (Ashinze, 2015).

Due to increase in the population, inability to use trade to avoid trade constraint and the heavy dependence on natural resources as export goods make developing economies the likely places to expect the Malthusian effects (Weil and Wilde, 2010). Therefore, the population trend of Nigeria shows as one of the fastest growing countries in the world. This fact coupled with civil war, riots, ethnic and religious crisis, Fulani herdsmen and farmer clashes and the terrorism unleashed by Boko Haram in the northern part of the country. Those incidences declines in the growth of the national output and the heavy dependence on the revenue from the sale of natural resources signpost the likelihood of the existence of the Malthusian effects as well as its relevance in the contemporary Nigerian economy.

Although as predicted by the Malthusian theory, the population of Nigeria has not grown geometrically over time, the growth has been however remarkable, while the envisaged "misery" or "vice" by the theory have continued to manifest in Nigerian economy (Ewugi and Yakubu, 2012). Due to the decline in the agricultural sector which was previously the leading sector in the 1960s, as a result of fall in investment and low technology in the industry, domestic food production has continued to fall behind the food required by the growing population which thus necessitate importation of food. The adoption of food to complement local food production shows the inability of Nigeria to feed their growing population. As predicted by Malthus, increase in Nigeria’s population has been supplemented by an increase in poverty and outbreak of disease such as HIV/AIDS, malaria, Ebola Virus, Lassa fever, etc. This fact is significant as more than $50 \%$ of the nation's population lives below the poverty line of $\$ 1.90$ a day. Though the adoption of population prevention checks has significantly improved, the practice is yet to fully adopted in Nigeria. Religious groups are acting against the passage of family planning; giving birth to unwanted babies and giving birth outside the hospital, which increases infant and maternal mortality, had considerably worked against the success of preventive checks in the country.

Several studies have been conducted both in developed and developing economies with the aim of validating the truism of the Malthusian theory of population growth. Specific studies do from the perspectives of economies and countries within the same region such as Africa and Asia. For example, Zhang (2015) using public data of ten Asian countries to investigate on the Analysis of the Correlation Between Population Growth and Economic Development in Asian Countries. Although based on Solow model which is concerned with the correlation between labor (skilled and unskilled) and growth of output, the author discovered that there exists an inverse relationship between the growth of population and output in some developing economies in Asia. Like China, India, Indonesia, Malaysia, and Indonesia, which is due primarily to the inability of the economy to absorb the growth of the population due to its population base which also fails to convert them into skilled labor. 
Although this is not the case of China and India due to the unavailability of skilled labor in India compared to China due to its educational situation.

Similarly, the Malthusian theory has investigated from country-specific level. For instance, Musa (2015) uses Indian time series data covering the period from 1980 to 2013 to empirically study the relationship between population growth and the economic development of India. Employing Johansen test for the long-run relationship among the pairs, and VECM to estimate the short-run dynamics of the variables shows the existence of long run and the proportionate relation between the growth of Indian population and its economic development. The Granger causality test further indicates the unidirectional relationship of causality is moving from economic development to growth of the population output. Ali, et al. (2013) using Pakistan time series data covering the period 1975 to 2008 to analyze the Impact of Population Growth on Economic Development in Pakistan. Employing ARDL estimation technique, the result obtained by the authors' shows that population has a significant and proportionate influence on the economic development of Pakistan although it (population) have a significant and inverse relationship with unemployment in Pakistan. In the same vein, Ali et al. (2015) use Bangladesh's time series data from 1981 - 2014 to empirically validate the Malthusian theory in Bangladesh. The authors employing a multivariate analysis discovered that there exists a significant and inverse relationship between the growth of population and output.

In Nigeria, certain scholars have attempted to study the validity of the Malthusian theory in the Nigerian economy. For example, Okwori et al (2015) used time series data covering a 31 years period of 1982 - 2012 to Empirically Investigate the Malthusian Population Theory in Nigeria. Using the Vector Error Correction (VEC) Mechanism, the result obtained shows that within the study period, the growth of Nigerian population does not have any significant influence on economic development. Similarly, Adediran (2012) conducted a quantitative analysis using OLS and time series data from 1981 to 2007 on the effect of the population of the economic development of Nigerian economy. The author's finding shows the existence of a proportionate relationship between population and the growth of the Nigerian economy. Babatunde and Ajayi (2010) use multi-regression analysis to study Food crisis and population growth in Nigeria. The authors thus discovered the existence of the substantial proportionate relationship between domestic food productions (maize, Rice, Beans, Plantain, Yam, Cassava, and Groundnut) in Nigeria with the population growth, which indicates the ability of food output of Nigeria to sustain its growing population. Oladimeji (2017) empirically examined the trend of rice production and importation parameters in Nigeria from 1960-2015 about the Malthusian theory. Employing correlation analysis and ANOVA the author affirm the exponential growth of population in Nigeria that related to the arithmetic increase in food production (local and imported rice). The author further discovers a proportionate relationship between the pairs an increase in population necessitates the increase in the demand for rice although the need for imported rice exceeds that of locally produced rice. Equally, in Nigeria, Aidi et al (2016) used Nigerian time series data from 1970 2013 to empirically investigate the evidence of causality between population growth the economic growth of Nigerian economy. Relying on the Granger causality test, the author discovered that there exists no causal relationship between population growth and economic growth in Nigeria falsifying the credibility of the Malthusian theory in Nigeria. 
Okoh et al (2017) used Nigerian time series data from 1986 to 2016 to study the impact of a growing population on agricultural output in Nigeria: An empirical analysis of the Malthusian hypothesis. Employing the Johansen co-integration test reveals the existence of a long-run relationship between agricultural production and population growth of Nigerian economy. The result from the long-run model in the study thus shows the presence of an inverse relationship between agricultural output and the growth of the population of Nigerian, affirming to the validity of the Malthusian effect in Nigeria. Finally, Osu (2017) investigates the dynamics of population and food security in Nigeria. Stratifying population in three groups and food production into (fishery, crops and livestock), the author discovered that while there exists an inverse relationship between the population with ages between 0-14 and 66 and above with food production, the population with ages $15-65$ has a positive influence on food production in the country.

Explicitly, few studies conducted to validate the Malthusian theory in Nigeria employed inappropriate estimation technique (see Ali et al., 2015; Adediran, 2012; Babatunde and Ajayi, 2010; Oladimeji, 2017; Abdulrahaman, 2013; Ahmad and Ali, 2016; Okoh et al., 2017). Because the unit root test was not conducted to determine the level of integration of the variables. The findings of Okwori et al. (2015) would have been clinched onto in validating Malthusian theory in Nigeria due to the use of a dynamic model (VECM) if not for the non-stationary of the variables at the level and first differencing which is assumed to produce a spurious regression result. Similarly, the inclusion of unnecessary variables in the model (see Ali et al., 2015; Ahmad and Ali, 2016; Okoh et al., 2015), and the negligence of crucial post-estimation test such as serial correlation, heteroscedasticity test, model stability test, etc. To ensure the model is free from these problems as well stable (see Ali et al., 2015; Okwori et al., 2015; Adediran, 2012; Babatunde and Ajayi, 2010; Abdulrahaman, 2013; Okoh et al., 2015) made it hard to clearly validate the truism of the Malthusian theory in the country. Thus this study will test the stationarity of the variables entering the model that will serve as a pre-test and determinant of the estimation technique that will be used for estimation and as well perform the necessary tests and diagnosis. Accordingly, the study will expand its scope to capture population growth from the period of the nation's independence (estimation of data from 1960 - 2016).

\section{Method}

As the study implies, data on population growth, food production, national output growth, and mortality rate will be time series data from 1960 to 2016 collected from a secondary source the World Bank World Development Indicators (WDI) and the Central Bank of Nigerian Statistical Bulletin. To effectively examine the validity of Malthusian theory in Nigeria, the study will employ the framework of Solow model which explains the growth of an economy in the long-run from the perspective of capital accumulation, population growth (labor) and changes in productively (technological progress), and it mathematically is given as:

$Y_{t}=K_{t}^{\alpha}\left(A_{t} L_{t}\right)^{1-\alpha}$

Where; $t$ denotes time; $0<\alpha<1$ is the elasticity of output with respect to capital; $Y_{t}$ 
denotes the total production; while $K, L$, and $A$ denotes capital, labour and labour augmenting technology (knowledge), Thus for this study we assume capital and knowledge to be fixed, thus equation. (1) transforms to;

$$
Y_{t}=L_{t}^{1-\alpha}
$$

$Y$ in equation (2) can be employed to capture food production in an economy while $L$ captures the population growth of an economy. Therefore, exponential growth in population which is given by the Malthusian model as;

$$
L_{t}=P_{0} e^{r t}
$$

Or by taking the natural log;

$$
L_{t}=\ln P_{0}+r t
$$

Where $L$ denotes population growth, $P_{0}$ is the initial population size, $r$ is the growth rate of population and $t$ denotes time. Thus combining equation can represent changes in food production. (4) and (2) as thus;

$$
Y_{t}=\left(\ln P_{0}+r t\right)^{1-\alpha}
$$

Alternatively, equation. (5) transforms to;

$$
Y_{t}=\left(\ln P_{r t}\right)^{1-\alpha}
$$

Food production or supply $Y_{t}$ in equation (6), which under the Malthusian theory is said to grow in an arithmetic progression due to the working of the law of diminishing returns and the fixed supply of land will be represented as FOOD with the assumption that food is the only commodity being produced in the economy. As such, the percentage of agricultural land and growth in agricultural sector of an economy will be incorporated into equation (6), with the former being fixed and negatively influence the expansion of food production after the point of maximum food production has being attained. Thus equation (6) is re-written as;

$$
F O O D_{t}=-\ln P O P_{t}-\sigma(A G R I C L A N D)+A G R
$$

Where $F O O D_{t}$ denotes food production at time $t$; AGRICLAND is the percentage of total land which is cultivated; $(0<\sigma<1)$ is amount of changes in food production due to the fixed supply of land; $P O P$ is the growth of population at time $t$ and $A G R$ denotes growth in the agricultural sector of the economy. For empirical analysis equation (8) is developed;

$$
\text { FOOD }_{t}=a-b_{1} \operatorname{lnPOP} P_{t}-b_{2} \text { AGRICLAND }_{t}+b_{3} A G R_{t}+\mu_{t}
$$

Where; $a, b_{1}-b_{3}$ are the parameters to be estimated; $\mu$ is the error tem; and other identities as previously stated. As a pretest, we check for the presence of unit root (non-stationarity) in the variables. If after checking for the unit root of the variables in equation (8), and all the variables are found to be stationary at levels (i.e. $\mathrm{I}(0)$ ), we estimate the variables using the OLS techniques for long-run estimation since they are all assumed to pose a long-run relationship due to their stationarity at levels. Else, if the variables are jointly integrated of order 1 (stationarity after first difference), we employ the Error Correction methodology in order to tie the long-run behavior of the variables to their short-run estimate through the lagged value of the error term. Accordingly if the variables are integrated of different orders not more than 1 (some being $\mathrm{I}(0)$ variables while others are $\mathrm{I}(1)$ variables) we employ the Autoregressive Regressive Distributive Lag (ARDL) model and bound testing for co- 
integration with the assumption that the inclusion of the lagged values of the dependent variable and the explanatory variables which are assumed to likely influence the dependent variable in the current period since its response to set of explanatory variables usually takes lapse of time. Thus if the variables in equation (8) are in all integrated of order 0 (stationary at levels) we estimate equation (8), else if the variables are jointly integrated of order 1 (stationarity after first difference) we estimate:

$$
\begin{aligned}
\text { Food }_{t}=\lambda_{0}+ & \lambda_{1} \sum_{i=0}^{n} \Delta \text { food }_{t-i}-\lambda_{2} \sum_{i=0}^{n} \Delta \operatorname{lnPop}_{t-i}-\lambda_{3} \sum_{i=0}^{n} \Delta \text { Agricland }_{t-i} \\
& -\lambda_{4} \sum_{i=0}^{n} \Delta \text { Agr }_{t-i}+\delta \text { Food }_{t}-a+b_{1} \text { lnPop }_{t}+b_{2} \text { Agricland }_{t} \\
& -b_{3} \text { Agr }_{t}+\mu_{t}(9)
\end{aligned}
$$

Equation (9) is thus an Error Correction dynamic model. $\delta$ is the coefficient of one period lag of error term, which can be alternatively written as $\delta \varepsilon_{t-1}$. Alternatively (9) can be re-written as: Food $_{t}=\lambda_{0}+\lambda_{1} \sum_{i=0}^{n} \Delta$ Food $_{t-i}-\lambda_{2} \sum_{i=0}^{n} \Delta \operatorname{lnPop} t-i-\lambda_{3} \sum_{i=0}^{n} \Delta$ Agricland $_{t-i}+$

$$
\lambda_{4} \sum_{i=0}^{n} \Delta A g r_{t-i}+\delta \varepsilon_{t-1}+\mu_{t}
$$

Accordingly, if the variables are integrated of different orders not more than 1 (some being $\mathrm{I}(0)$ while others are I(1)), we can't directly estimate the Error Correction model in equation (10), else the ARDL model and bound testing for co-integration will be employed first to ascertain the existence of co-integration among the variables in the model. Thus instead of equation (10) we transform equation (8) to a conditional ECM after which equation (10) will be estimated as the short-run estimates of the model. Therefore, we develop the conditional ECM as thus

$$
\begin{aligned}
\text { Food }_{t}= & \lambda_{0}+\lambda_{1} \sum_{i=0}^{n} \Delta \text { Food }_{t-i}-\lambda_{2} \sum_{i=0}^{n} \Delta \operatorname{lnPop}_{t-i}-\lambda_{3} \sum_{i=0}^{n} \Delta \text { Agricland }_{t-i}+ \\
& \lambda_{4} \sum_{i=0}^{n} \Delta \text { Agr }_{t-i}+\delta \varepsilon_{t-1}+\theta_{1} \text { Food }_{t-1}+\theta_{2} \text { LnPop }_{t-1}+ \\
& \theta_{3} \text { Agricland }_{t-1}+\theta_{4} \text { Agr }_{t-1}+\mu_{t}
\end{aligned}
$$

Where; $\theta_{1}-\theta_{1}$ are the parameters of the one period lag of level variables in the dynamic model, whose coefficient would be used to test against the critical values provided by Pesaran, et al (2001). If the variables are co-integration we estimate granger causality test:

$$
\begin{aligned}
& \text { Food }_{t}=\lambda_{0}+\lambda_{1} \sum_{i=0}^{n} \text { Food }_{t-i}+\lambda_{2} \sum_{i=0}^{n} \operatorname{lnPop}_{t-i}+v_{i} \\
& \operatorname{lnPop}_{t}=\lambda_{0}+\lambda_{1} \operatorname{lnPop}_{t-i}-\lambda_{2} \sum_{i=0}^{n} \text { Food }_{t-1}+v_{i} \\
& \text { lnAgricland }_{t}=\lambda_{0}+\lambda_{1} \sum_{i=0}^{n} \text { Agricland }_{t-1}-\lambda_{2} \sum_{i=0}^{n} \text { Agr }_{t-1}+v_{i} \\
& \text { lnAgr }_{t}=\lambda_{0}+\lambda_{1} \sum_{i=0}^{n} \text { Agr }_{t-1}-\lambda_{2} \sum_{i=0}^{n} \text { Agricland }_{t-1}+v_{i}
\end{aligned}
$$

\section{Results and Discussion}

Prior to the requirement for the test of the stationarity of the variables in the mode, the Augmented Dickey-Fuller (ADF) unit root test is employed. ADF unit root test tests the null hypothesis that the series have unit root (not stationary) against the alternative hypothesis that the series does not have a unit root. The null hypothesis thus rejected by the value of $\mathrm{ADF}$ statistics exceeding the critical values at either $1 \%, 5 \%$ or $10 \%$. Although if a series is found to have unit root at series (not stationary) at the level, the series can 
be differenced once or twice (although series stationery after second differencing not appreciated in econometrics) to make stationary with the assumption of either constant, trend or none entering the equation.

Table 1. Result of Unit Root Tests

\begin{tabular}{cccc}
\hline Variables & ADF Statistics & 5\% Critical Value & Order of Integration \\
\hline FOOD & $-1.953189^{*}$ & -1.947381 & $\mathrm{I}(1)$ \\
InPOP & $-3.389786^{*}$ & -2.923780 & $\mathrm{I}(0)$ \\
AGRICLAND & $-7.752803^{* *}$ & -1.947248 & $\mathrm{I}(1)$ \\
AGR & $-5.726378^{*}$ & -2.951125 & $\mathrm{I}(0)$ \\
\hline
\end{tabular}

Assumptions - ${ }^{*}$ (Intercept only) and ${ }^{* *}$ (No Intercept and Trend)

The result from unit root tests employed using ADF test as presented in Table 1 shows that the series (FOOD, InPOP, AGRICLAND and $A G R$ ) are mixture of $\mathrm{I}(0)$ and $\mathrm{I}(1)$. That is FOOD and AGRICLAND are stationary after first difference, while InPOP and $A G R$ are stationary at levels. Hence, since the series are integrated of different order not more than 1 , as stated in the previous section, we employ the ARDL method and the Bound testing approach for co-integration.

Since the series are the mixture of I(0) and I(1) we employ the ARDL bound testing approach for co-integration. The ARDL bound test is performed on the basis of comparing the test statistics (f-statistics and t-statistics) with the critical values provided by Pesaran et al (2001) to test the null hypothesis that there exists no co-integration (or long-run relationship) among the series against the alternative hypothesis that there exist co-integration among the series. The f-statistics that is compared against the critical values is obtained using the Wald statistics to test the null hypothesis of the coefficients of the levels variables in the conditional ECM $\left(\theta_{1}-\theta_{1}\right)$ in equation (11) jointly being equal to zero. If the computed f-statistics from Wald statistics exceeds the upper bound $(\mathrm{I}(1))$ we reject the null hypothesis of no co-integration while we fail to reject the null hypothesis when the computed f-statistics is less than the lower bound $(\mathrm{I}(0))$. We are thus indecisive when the f-statistics falls between the lower bound $(\mathrm{I}(0))$ and upper bound (I(1)).

Table 2. Result from Bound Test

\begin{tabular}{cccc}
\hline $\begin{array}{l}\text { F-Statistics }=8.004942 \\
\text { Asymptotic critical value bounds for the F-statistic (Pesaran et al (2001) Case II) }\end{array}$ & $\mathrm{K}=3$ \\
\hline \multicolumn{1}{l}{$1 \%$} & $\mathrm{I} \%$ & $\mathrm{I}(1)$ \\
3.65 & $\mathrm{I}(1)$ & 2.79 & 3.67 \\
\hline
\end{tabular}

Source: Author(s) Computations Using E-Views 9

The results of the bound test as presented in Table 2 shows that the f-statistics (8.004942) are more significant than the upper bound at 1\% and 5\% respectively. This result implies that there exists a long-run relationship between food production and the growth 
of Nigerias population (and percentage of agricultural land and the growth of agricultural sector). Before estimating and presenting the long run and short-run estimates of the models shown in the previous section. We test the pairwise causality between the variables in the model, by examining the null hypothesis that explanatory variables in equation (12) down to equation (12) does not Granger cause the variables on the left-hand side against the alternate hypothesis that they Granger cause the variables. The f-statistics with the corresponding p-value, which used for inference obtained from the Wald statistics in the relevant models. Particular reference will be given to the pairwise causality between population growth (POP) and food production (FOOD).

Table 3. Pairwise Granger Causality Test

\begin{tabular}{lccl}
\hline Null Hypothesis: & Obs & F-Statistic & Prob. \\
\hline LOG(POP) does not Granger Cause FOOD & 52 & 1.31444 & 0.2783 \\
FOOD does not Granger Cause LOG(POP) & & 0.46717 & 0.6297 \\
AGRICLAND does not Granger Cause FOOD & 52 & 1.56379 & 0.2200 \\
FOOD does not Granger Cause AGRICLAND & & 0.53944 & 0.5866 \\
AGR does not Granger Cause FOOD & \multirow{3}{*}{31} & 0.44153 & 0.6478 \\
FOOD does not Granger Cause AGR & & 0.39237 & 0.6794 \\
AGRICLAND does not Granger Cause LOG(POP) & 52 & 0.44906 & 0.6409 \\
LOG(POP) does not Granger Cause AGRICLAND & & 3.72665 & 0.0315 \\
AGR does not Granger Cause LOG(POP) & 33 & 0.00817 & 0.9919 \\
LOG(POP) does not Granger Cause AGR & & 1.65215 & 0.2098 \\
AGR does not Granger Cause AGRICLAND & 31 & 1.02917 & 0.3714 \\
AGRICLAND does not Granger Cause AGR & & 0.98460 & 0.3871 \\
\hline
\end{tabular}

Source: Author(s) Computations Using E-Views 9

From Table 3, we fail to reject the null hypotheses in equation (12) and equation (13), it thus shows that there exist no Granger Causality running from either POP to FOOD nor FOOD to POP. Although, there is a one-way Granger causality running from POP to AGRICLAND, but not the other way round in the system. This result is in line with Aidi, et al (2016).

Since the Granger Causality test had been carried out and the existence of long-run relationship have been established among the variables in the model by the ARDL bound testing approach, the long-run estimate that is analogous to equation (8) present in Table 4. From the long-run forecasts in Table 4, all the variables in the model (apart from growth in the agricultural sector) are statistically significant at $10 \%$ level Significance and has a proportionate relationship with food production index in Nigeria. Changes in the population growth of Nigeria accompanied by a proportionate increase in food production and against the assertions of the Malthusian theory. Thus on average, a percent increase in the rate of growth of Nigerian economy at a specific time will trigger an increase in food production by $27,536.05$ tons in the period. This result thus disproves the assertions of the Malthusian 
theory that food production grows in an arithmetic progression compared to the geometrical progression in population growth in every quarter of a century (or in the long-run) in Nigeria.

Table 4. Long-Run Estimates

Dependent Variable: FOOD

\begin{tabular}{ccccc}
\hline Variables & Coefficient & Std. Error & t-Statistics & Prob. \\
\hline Contant & -574.2953 & 241.7197 & -2.375872 & 0.0271 \\
In(POP) & 275.3605 & 201.3574 & 1.367521 & 0.1859 \\
AGRICLAND & 5.623226 & 1.221976 & 4.601747 & 0.0002 \\
AGR & 1.359744 & 1.111422 & 1.223427 & 0.2347 \\
\hline
\end{tabular}

Source: Author(s) Computations Using E-Views 9

This result did not tally with the empirical finding of Ali et al. (2015), Okwori et al (2015) and Zhang (2015). This result might likely be due to location difference and the period considered. Thus this outcome depicted modern theory of population doctrine; given a certain amount of resources, state of technical knowledge and a specific stock of capital, there will be a definite size of the population at which real income of goods and services per capita will be the highest. Accordingly, the percentage of land used for agricultural practice and agricultural sector's growth in Nigerian both positively influence food production in Nigeria. Averagely, a percent change in the area used for agriculture will result to about 562.3 tons increase in food production while 135.97 tons of food production will increase as a result of growth in the agricultural sector of the economy. Although, the law of diminishing returns (or variables proportion) is applicable when a factor of production fixed (land). Thus changes in the percentage of land used for agriculture as the population increases as well as attainment of growth in the agricultural sector of an economy. As a result of the use of technological improved machines and implements (such as tractor, harvester, millers, storage systems, etc.) will cause food production to increase positively. As well, it also depicts the ability of Nigerian agricultural sector to feed the ever-growing population.

As such, since the long-run relationship among the variables has been confirmed and the levels regression (long-run estimates) presented above, the analogous short-run estimates analyzed using ARDL-ECM that corresponds to equation (10) is presented in Table 5. The optimum lag length of the ARDL model of $(2,1,1,2)$ guided by the Adjusted R2 as a model selection criterion.

From the short-run estimates in Table 5, the population growth of Nigeria negatively influences food production, which thus corroborates with the assertions of Malthusian theory. On average, a percent change in the growth of Nigerian population will cause food production to decline by 28,418.9 tons. This result supports the Malthusian theory and the empirical findings of Okwori et al. (2015), Ali et al. (2015), Zhang (2015), Okoh et al. (2017) and Ali et al. (2013). This result is refuting the findings of Musa (2015) and Adediran (2012). This result implies that instead of population growth outstripping food production due to the progressive geometric growth in the past and arithmetic progressive growth in latter at every quarter of a century (25 years) as asserted by the Malthusian theory, this is obtainable in the 
current period of population changes. In the long-run increase in food production due to improvement in agricultural mechanisms is obtained even with the increase in more mouths to feed. The attention shift of the Nigerian economy from the agricultural sector to service and oil and gas sector coupled with the use of crude farm tools such as hoe and cutlass are likely causals of this decline in food productivity.

Table 5. Short-run ECM Estimates

Dependent Variable: $\triangle F O O D$

\begin{tabular}{lcccc}
\hline \multicolumn{1}{c}{ Variables } & Coefficient & Std. Error & t-Statistics & Prob. \\
\hline$\triangle F O O D(-1)$ & -0.660575 & 0.111044 & -5.948756 & 0.0000 \\
$\Delta \operatorname{In}($ POP $)$ & -284.1890 & 81.43209 & -3.489889 & 0.0022 \\
$\triangle A G R I C L A N D$ & 1.843025 & 0.312567 & 5.896415 & 0.0000 \\
$\Delta A G R$ & 0.023132 & 0.046233 & 0.500339 & 0.6220 \\
$\Delta A G R(-1)$ & -0.110946 & 0.046197 & -2.401582 & 0.0257 \\
$\varepsilon_{t-1}$ & -0.107561 & 0.015582 & -6.902787 & 0.0000 \\
$\mathrm{R}^{2}$ & 0.707074 & & & \\
Adj. $\mathrm{R}^{2}$ & 0.648489 & & & \\
Durbin-Watson & 1.846280 & & & \\
\hline
\end{tabular}

Source: Author(s) Computations Using E-Views 9

Similar to what is obtainable in the long-run estimates in Table 4, changes in the percentage of land used for agriculture and the growth of the agricultural sector positively influences food production. On average, when the proportion of area used for agriculture and the growth of the agricultural sector changes by a percent, it will result in 184.3, and 2.31 tons increase in food production in Nigeria respectively. Although the past year growth of agricultural sector negatively influences food production, this is likely due to the slowdown in the sector as a result of oil dependence that afterward revitalized when the price of oil in the international market fell.

In the same vein, the coefficient of the one period lagged error correction term $\left(\varepsilon_{t-1}\right)$ which measures the speed of adjustment towards long-run equilibrium as expected is negative, less than 1 and highly statistically significant. Therefore going by the coefficient of the one period lagged error correction term, disequilibrium or deviations in food production will correct towards long-run equilibrium at the speed of approximately $11 \%$ a year. The $\mathrm{R}^{2}$ is good fit, shows $71 \%$ total variation in explanatory variables in explaining dependent variable.

Overall, the short-run estimates suggest the validity of Malthusian theory in Nigeria. This result thus demonstrates the decline in food production as the population grows. Recently Nigerian health minister made a shocking revelation that the growth of the Nigerian population if unchecked will result in an adverse effect on the national resources. This result is thus synonymous with the predictions of the Malthusian theory. Although in advance economies, population and food production have a proportionate relationship, with food production growing even faster than the growth of population. This result is due to technological advancement in agriculture that is still lagging behind in Nigeria, coupled with 
the control in the number of children born by couples. Advanced economies practice birth control, which serves as a check on the growth of population. Consequently, the adoption of both control measure is seen as an aberration in certain parts of the Nigerian state. Therefore, this is many more reasons are likely to lead to the inability to invalidate the predictions of the Malthusian theory in Nigeria.

Table 6. Diagnostic Tests

\begin{tabular}{ll}
\hline Test Statistics & Result \\
\hline Autocorrelation: Chi-Sqr(2) & $0.1476(0.9557)$ \\
Heteroscedasticity: Chi-Sqr(9) & $14.1532(0.1170)$ \\
Normality: Jaque-Bera & $0.6311(0.7294)$ \\
Functional Form: Ramsey RESET F-stat(1,20) & $2.4598(0.1325)$ \\
\hline
\end{tabular}

Source: Author(s) Computations Using E-Views 9

The diagnostics tests for autocorrelation, heteroscedasticity, normality and model stability presented in Table 6 shows the correctness of the model as it does not violates the classical linear assumption of no serial correlation, homoscedasticity, normality, and model stability. Accordingly, the error correction term $\left(\varepsilon_{\mathrm{t}-1}\right)$ rightly stated, as it is negatively less than 1 and highly statistically significant.

\section{Conclusion}

The predictions of the Malthusian theory coupled with the growth of Nigerian economy, which placed it as the most populated in Africa and 7th in the world and the divergence of the economy's attention from agriculture necessitates the empirical validations of the Malthusian theory in Nigeria. This study thus employs the ARDL bound testing technique to empirically validate the Malthusian theory in Nigeria using data from 1960 to 2016 and also taking into cognizance in the role played by land and the agricultural sector under the Malthusian theory. The result, therefore, suggests the existence of co-integration among the variables in the model. The population growth and food production have a positive relationship in the long-run while exhibiting an inverse relationship in the shortrun. Although, the percentage of land used for agriculture and the growth of the Nigerian agricultural sector influences food production positively both in the short-run and longrun. This result suggests the validity of Malthusian theory in the Nigerian economy.

Therefore, based on the result obtained from this study, the following policies are recommended: First, Government should integrate redistribution policies into the complete economic development plan to reduce the rate of emigration, through stressing rural development (e.g., incentives for firms to set up in rural areas). Further, it should move some government offices to rural areas. The government also needs to adopt population policies encouraging the lowering of fertility levels. If it were to provide education through the secondary and prevocational education level free of charge, educated women would lower their fertility. Sex education should include in the curriculum. Further, the government must 
play an active role in family planning programs, especially educating rural women about family planning. It should also use the mass media to promote small family size, but it should not dictate family size. It also needs to recognize that population growth puts much pressure on the environment. Second, The percentage of land use for agricultural practices should increase as it tends to increase the supply of food, this can do through effective land use act which will make the procurement of land for agricultural practices affordable for all economic class in the country. Third, in the same vein, students and youths should inculcate with agricultural activities and small-scale entrepreneurial activities, as it will lessen the pressure of unemployment in the country as well make the growing population more productive and agents of growth to the nation's economy.

Fourth, the agricultural sector of the Nigerian economy should overhaul by way of improving the use of the technological advance mechanism, which will enhance the productivity of the sector. Fifth, increasing saving rate of Nigerians should increase, as this will be used to invest in more research and new techniques. Each of these methods being a less than perfect substitute requiring more labor or resource of a different, more labor intensive type and therefore added more value-added services to the production. This policy continues to add to the total output at a higher rate than population growth, raising per capital out as a result. Sixth, policymakers need to be careful too when trying to influence the economy through changes in macroeconomic variables such as money supply or interest rate. Finally, the special agricultural intervention such subsidization of agricultural inputs and provision of soft loans to farmers should be taken up by the government at all levels through the agricultural sectors. This policy will go a long way in increasing farmer's productivity.

\section{References}

Abdulrahaman, S. (2013). Population Growth and Food Security in Nigeria (2010-2012). Arabian Journal of Business and Management Review (Nigerian Chapter). Vol. 1 (3): 41-63.

Adediran, O.A. (2012). Effect of Population on Economic Development in Nigeria: A Quantitative Assessment. IJPSS, Vol. 2 (5): 1-14.

Ahmad, K. \& Ali, A. (2016). Rising Population and Food Insecurity Linkages in Pakistan: Testing Malthusian Population Growth Theory. Munich Personal RePEc Archive (MPRA). Retrieved from https://mpra.ub.uni-muenchen.de/71131/

Aidi, H.O., Emecheta, C. \& Ngwudiobu, I.M. (2016). Population and Economic Growth in Nigeria: is there an Empirical Evidence of Causality?. International Journal Advances in Social Science and Humanities. Vol. 4 (2): 59-66.

Ali, S., Alam, K.J., Islam, S. \& Hossain, M. (2015). An Empirical Analysis of Population Growth on Economic Development: The Case Study of Bangladesh. International Journal of Economics, Finance and Management Sciences. Vol. 3 (3): 252-259.

Ali, S., Ali, A. \& Amin, A. (2013). The Impact of Population Growth on Economic Development in Pakistan. Middle-East Journal of Scientific Research. Vol. 18 (4): 483-491.

Ashinze, A.N. (2015). A Robust Model for The growth of the Nigerian Population. IOSR Journal of Mathematics (IOSR-JM). Volume 11 (6): 65-69 
Babatunde, B.O. \& Ajayi, S.O. (2010). Food Crisis and Population Growth in Nigeria. Manager Journal. Vol. 11 (1): 180-187.

Chand, S (2017). Malthusian Theory of Population: Criticisms and Applicability. Your Article Library. Retrieved November 29, 2017, from http://www.yourarticlelibrary.com/ population/malthusian-theory-of-population- criticisms-and-applicability/10885

Ewugi, M.S. \& Yakubu, I. (2012). Malthusian Population theory and the Nigerian Economy: A Political Economy Approach. International Journal of Human Resource Studies. Vol. 2 (4): 197-206.

Friedman, P. (2000). Grolier, Encyclopedia of Knowledge. Vol. 15, USA. In Ewugi, M.S. and Yakubu, I. (2012). Malthusian Population theory and the Nigerian Economy: A Political Economy Approach. International Journal of Human Resource Studies. Vol. 2 (4): 197-206.

Hanson, J.L. (1971), "A Textbook of Economics". 5th edition, MacDonald and Evans, London. In Ewugi, M.S. and Yakubu, I. (2012), "Malthusian Population theory and the Nigerian Economy: A Political Economy Approach". International Journal of Human Resource Studies, Vol. 2, No. 4, pp. 197-206.

Harley, R. (2017), "Malthusian Theory of Population Growth: Definition \& Overview”. Retrieved November 29, 2017, from http://www.study.com/academy/lesson/ malthusian-theory-ofpopulation-growth-definition-lesson-quiz.html

Musa, A.M. (2015). Econometric Model on Population Growth and Economic Development in India: An Empirical Analysis. Proceedings of the International Symposium on Emerging Trends in Social Science Research (IS15Chennai Symposium), Chennai-India, 3-5 April 2015 Paper ID: C539.

Seth, T. (2017). Malthusian Theory of Population: Explained with its Criticism. Retrieved November 29, 2017, from http://www.economicsdiscussion.net/articles/ malthusiantheory-of-population-explained-with-its-criticism/1521

Okoh, A.S., Ojiya, E.A. \& Chukwu, S.N. (2017). The Impact of a Growing Population on Agricultural Output in Nigeria: An Empirical Analysis of the Malthusian Hypothesis. Basic Research Journal of Business Management and Accounts. Vol. 6 (1): 38-50.

Okwori, J., Ajegi, S.O., Ochinyabo, S. \& Abu, J. (2015). An Empirical Investigation of Malthusian Population Theory in Nigeria. Journal of Emerging Trends in Economics and Management Sciences (JETEMS). Vol. 6 (8): 367-375.

Oladimeji, Y. U. (2017). Food Production Trend in Nigeria and Malthus Theory of Population: Empirical Evidence from Rice Production. Nigerian Journal of Agriculture, Food and Environment. Vol. 13(1): 126-132.

Osu, A.K. (2017). Population Dynamics and Food Security in Nigeria. International Journal of Advanced Studies in Economics and Public Sector Management. Vol. 5, (2): 129 - 139.

Weil, D. N. \& Wilde, J. (2010). How Relevant Is Malthus for Economic Development Today?. American Economic Review. Vol. 100, (2): 378 - 382.

Zhang, S. (2015). Analysis of the Correlation between Population Growth and Economic Development in Asian Countries. Cross-Cultural Communication. Vol. 11 (11): 6 - 11. 